\title{
Early Acquisition of Nominal Plural in Spanish*
}

\section{Conxita Lleó}

Universität Hamburg. Institut für Romanistik

Von-Melle-Park 6, 20146 Hamburg (Deutschland)

lleo@uni-hamburg.de

\begin{abstract}
This paper examines the development of nominal plural formation in Spanish by three monolingual and two Spanish-German bilingual children, from the beginning of word production until at about $2 ; 4-3 ; 0$, depending on data availability. Some children begin to express plurality by means of a final - $e$ (belonging to the Spanish allomorph -es), whereas other children, one of the monolinguals and the two bilinguals, produce plural final $-s$ from the beginning. These results are correlated to the child-specific accessibility of final codas in lexical items. On the one hand, such a correlation leads to the postulation of a relative dependency of morphology on phonology: only accessible phonological material can provide morphology with the means to express its categories. However, even if the phonological means have not yet been acquired, the child can still express morphological categories, which are then incomplete, and often ignored in analyses that do not take phonology into consideration.
\end{abstract}

Key words: morphological acquisition, phonological acquisition, prosodic structure, plural, allomorphs, coda consonants, monolingual and bilingual acquisition.

\section{Table of Contents}

\section{Introduction 4. Conclusions}

2. Study of the Spanish nominal plural References

\section{Discussion}

\section{Introduction}

Spanish has a very regular nominal plural formation, based essentially on the addition of two allomorphs, /-s/ or /-es/ to the stem of the noun. It is thus to be expected that the expression of plurality should be mastered easily by children acquiring Spanish. However, plurality involves some further intricacies. In the first place, it involves some conceptual complexity, i.e. being able to refer to sets of individuals, which has often been addressed in the literature (see e.g. Bloom \& Wynn 1997). Secondly, although Spanish has a relatively simple expression of plurality at the

* I am grateful to the Deutsche Forschungsgemeinschaft and to the Collaborative Research Center on Multilingualism, of the University of Hamburg, which have made possible data collection and data analyses. I also want to thank the Research Assistants of the Project, Margaret Kehoe, Imme Kuchenbrandt and Martin Rakow for their help, as well as the Student Assistant, Julia Oellingrath, who began analyzing María's and Miguel's data in the frame of her Master's Thesis. 
morphophonological level, morphosyntactically not only nouns must be marked for plurality; determiners and adjectives, attributes as well as predicates, must be marked, too. The latter may be a complicating factor in the acquisition of plurality. Besides, as Bernhardt \& Stemberger (1997: 635ff) point out, not much is known on the acquisition of allomorphy. Spanish can thus provide evidence for the acquisition of a relatively simple allomorphy, and a redundant morphosyntactic realization. Given its regularity, it suggests the question whether children easily learn the generalization underlying plural formation in nouns, or whether they rather learn it in a piece-meal fashion, as it has been suggested for other areas of morphology, namely verbal morphology (Mueller Gathercole et al. 1999, Sebastián et al. 2001). Moreover, what appears as a very simple general rule makes use of complex phonological means, namely, a coda consonant, which tends to not be produced at the early stages of acquisition, especially not by children acquiring languages with strong coda constraints, as it has been shown for different languages (see e.g. Lleó 2003b for Spanish or Ota 2003 for Japanese). This poses the question whether plurality might be conceptually available, but not producible, just because the phonological means to express it are not yet accessible.

In relation to the latter issue, another question suggests itself: does the need to express plurality foster the production of coda consonants? That is, it is possible that, as Freitas et al. (2000) have argued for Portuguese, children acquire the final consonant expressing plurality before they learn to produce other final consonants. Furthermore, once there is some clarity on how monolingual Spanish children acquire the expression of plurality, the question can be raised about how bilingual children acquire it. Specifically, in the case of Spanish-German bilinguals, German being a language in which the plural allomorphs are not phonologically, but essentially lexically conditioned (see e.g. Wegener 1995), the question arises whether the simultaneous acquisition of the German system may perhaps slow down the acquisition of the Spanish generalization, as it has been shown in many studies that the two grammars of the bilingual child manifest interaction (Paradis \& Genesee 1997, Lleó 2002, 2003a).

The present article aims at addressing some of the issues related to the acquisition of plurality in the nominal constituents in Spanish. It is organized as follows. After presenting a summary of plural formation in Spanish (section 1.1 and 1.2) and reviewing the literature on plural acquisition (section 1.3), the questions and aims of the present study are introduced (section 1.4). Section 2 presents the data and results for the acquisition of plural in Spanish by three monolingual Spanish and two bilingual Spanish-German children; it relates morphological and phonological acquisition by mapping the development of plural/-s/ in relation to final coda production, and it examines the production of plural marking in nouns in relation to its production in determiners. Results are discussed in section 3, and a conclusion is presented in section 4 .

\subsection{Plural Formation in Spanish}

Core plural formation is very simple in Spanish: essentially, there are two allomorphs, /-s/ after noun stems ending in a vowel, as sg. casa 'house', pl. casa-s, or 
sg. oso 'bear', pl. oso-s, and /-es/ after noun stems ending in a consonant, as sg. flor 'flower', pl. flor-es, or sg. canción 'song', pl. cancion-es. If the stem ends in a stressed vowel, /-es/ is generally chosen, except in the case of stressed [e], which just adds /-s/, as in sg. café 'coffee', pl. café-s. Examples for the other final stressed vowels are $-i$ and $-\dot{u}$, as in sg. rubi 'rubi', pl. rubi-es, which in fact alternate with the /-s/ mark. That is, both plurals are possible in Spanish: rubi-es as well as rubi-s. Such words with varying plural endings are rather infrequent, and play hardly any role in early child language. Stems ending in [s], like dosis 'dosis' or martes 'Tuesday', which take no additional plural mark, are also rather infrequent in the early lexicon; if present, like in the case of the days of the week, they generally do not appear in a plural context.

Conceiving of these data as input for the child who is acquiring language, core plurals in /-s/ and /-es/ differ from each other in that words ending in a vowel only have the final coda/-s/ to mark the plural, whereas words ending in a consonant have two marks for plurality: the vowel /-e/, and the coda consonant/-s/. Besides being marked in the noun, plurality must also be marked in other accompanying words, determiners and/or adjectives. There are some subtle differences in the morphophonological way, in which different functional words get their plural marks, as shown in Table 1, where plural marks have been boldfaced.

At first sight, all three classes of words shown in Table 1 have just the typical /-s/ ending in the plural. This is especially true for the feminine forms, which just add /-s/ to the feminine /-a/ ending. However, all masculine forms have an additional vocalic mark that differentiates singular and plural: masculine plurals always end in /-os/, whereas the singular involves the vowel/e/ in the case of the definite article and the demonstrative, and no final vowel in the indefinite article. It can thus be said that the masculine forms have two marks to indicate plurality, the vowel (corresponding to gender) and the consonant. Finally, adjectives follow the core pattern of noun plural formation: if the stem ends in a vowel, generally /-o/, /-a/ or /-e/, the mark /-s/ is added, and if the stem ends in a consonant, /-es/ is added. Given that plural markings appear in most words in the sentence (not only in the $\mathrm{NP}$ or $\mathrm{DP}^{1}$, but also in the predicative adjectives), a typical plural phrase in Spanish is as in (1), where nominal plural marks have been underlined.

Table 1. Plural Formation of Determiners.

\begin{tabular}{lllllll}
\hline & \multicolumn{2}{l}{ Definite Article } & \multicolumn{2}{c}{ Indefinite Article } & \multicolumn{2}{c}{ Demonstratives } \\
& Sg. & Pl. & Sg. & Pl. & Sg. & Pl. \\
\hline Masc. & el & los & un & unos & este & estos \\
\hline Fem. & la & las & una & unas & esta & estas \\
\hline
\end{tabular}

1. I do not go into the debate whether DPs should take the theoretical place of NPs, or of some NPs, the non-predicative ones (see e.g. Abney 1987 for the original proposal, and Zagona 2002 for its application to Spanish), because this very debated issue is not decisive for our analysis of plural marking, which focuses on the morphophonological level. 


\section{(1) Plural Agreement}

$\mathrm{Sg}$. Este chico es fuerte

'This guy is strong'

Pl. Estos chicos son fuertes

'These guys are strong'

Sg. El pez es azul

'The fish is blue'

Pl. Los dos peces son azules

'These two fish are blue'

\subsection{Morphophonological representation of the plural allomorphs}

The brief description of plural formation presented in section 1.1 corresponds to the traditional view (see e.g. Real Academia Española 1931), which was formalized by Saporta (1965) by means of an allomorphy rule that defines the phonological conditions for the allomorphs: /-s/, /-es/ and null. This description was criticized in early generative times for not offering a principled account of allomorphy, since Saporta's rule was just a mere list of allomorphs in their contexts, without offering any explicit phonological foundation for why the three allomorphs are as they are. Two types of analyses tried to incorporate the phonological foundation into the plural formation rule, in order to reduce it to one single morph, namely /-s/, the others being derivable by phonological context. Foley (1967) based his analysis on an apocope rule for final /e/: words ending in a consonant included final /e/ in their stem, and this was deleted in the singular, but not in the plural. Saltarelli (1970), on the contrary, did not include such final /e/s in the stems of words ending in a consonant, but introduced them in the plural by means of a process of final epenthesis, a rule which he claimed to mirror initial epenthesis. Notice that these two analyses do not disagree as regards stems ending in a vowel, but only as far as those ending in a consonant. Table 2 illustrates these two analyses by means of a word ending in a consonant, i.e. árbol 'tree'.

Both analyses try to reduce allomorphy by phonological conditioning, but they both are confronted with some difficulties. In Foley's analysis words like sol 'sun' (pl. soles) with a final consonant and mole 'bulk' (pl. moles) with a final /e/ are

Table 2. Generative analyses of Plural Formation: On the bases of Apocope (Foley 1967) and Epenthesis (Saltarelli 1970).

\begin{tabular}{llllll}
\hline & \multicolumn{2}{c}{ Apocope Analysis } & & \multicolumn{2}{c}{ Epenthesis Analysis } \\
\hline & $\mathrm{Sg}$. & $\mathrm{Pl}$. & & $\mathrm{Sg}$. & $\mathrm{Pl}$. \\
\hline U Form & árbole & árbole-s & U Form & árbol & árbol-s \\
\hline Apocope & $\mathrm{e} \rightarrow \varnothing$ & --- & Epenthesis & --- & $\varnothing \rightarrow \mathrm{e}$ \\
\hline P Form & árbol & árboles & P Form & árbol & árboles \\
\hline
\end{tabular}


both provided with a final stem vowel in the underlying form. The vowel shows up in the plural, but only sol undergoes apocope. The reason for applying apocope can thus not be solely phonological, as both underlying forms, /sole/ and $/ \mathrm{mole} /$ are phonologically similar. Saltarelli's analysis would fare better for such cases, because only mole would end in the vowel /e/ in its underlying form. However, this analysis cannot explain the fact that the singular of a word like vals 'waltz' does not undergo epenthesis, whereas the plural of *arbols does, in spite of the fact that both words end in /-ls/ in their underlying representations (see Roca 1996 for discussion). Harris (1980) favors the epenthetic analysis, and proposes a solution framed in Autosegmental Phonology, which takes advantage of the morphological structure of words, distinguishing final segments that belong to the root of the word from those that correspond to word markers or terminal elements, as they have been dubbed in Harris (1991). The mechanics of this treatment largely lie on the postulation of a prosodic template for Spanish nouns and adjectives, of the form shown in (2a), which is applied to different types of words as shown in (2b) for singular forms like libro 'book', mole 'bulk' and vals 'waltz', and in (2c) for the corresponding plurals:

(2a) $\left[\begin{array}{llll}{[. .} & \mathrm{V} & \mathrm{C}\end{array}\right]_{\mathrm{N} / \mathrm{A}}$

(2b)

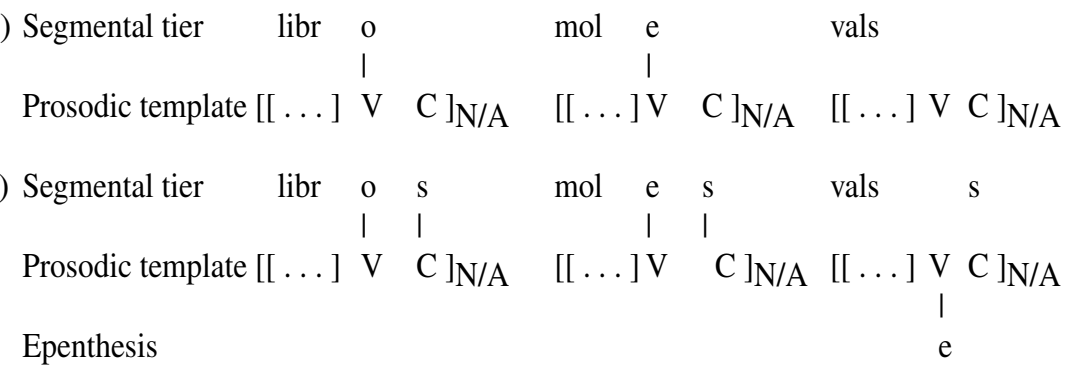

Roca (1996), on the contrary, argues that the apocope analysis is superior to the epenthesis one. His solution, though, is based on a distinction between the full vowel /e/ of mole, versus an underspecified vowel /v/ appearing in cases like sg. sol and pl. soles, which is represented as $/ \mathrm{sol}<\mathrm{v}>/$ in its underlying form; only such underspecified vowels will be deleted in word final position, not the fully specified one of mole. This type of solution works, but at the cost of using phonological features as diacritics, interpreting thus as fully phonological what is partially lexical.

The postulated phonological representation of words is thus prejudiced by the goal of reducing alternants to phonologically conditioned ones. However, the fundamental question relating to the acquisition of plural formation is what representation Spanish children assume for singular and plural forms, especially for those nouns that end in a consonant in the singular, and in [-es] in the plural. Most words ending in [e] in the singular, like mole 'bulk', prole 'offspring', pene 'penis', base 'base', sede 'seat', cruce 'crossing' are either abstract or learned nouns, which do 
not generally belong to a young child's lexicon. Words ending in a stressed vowel, like bajá 'pasha', carmesí 'crimson', rondó 'rondo', tisú 'brocade', etc. as already mentioned in section 1.1 are generally not part of it, either. And the same is true for words ending with an unstressed syllable closed by /s/, like lunes 'Monday'or dosis 'dosis', which take the null allomorph. This leaves us with the core nouns ending in an unstressed vowel (or stressed /e/, like pié 'foot'), which simply take /$\mathrm{s} /$, and those ending in a consonant, which take the allomorph /-es/. Do the underlying forms contain the final [e] or is the vowel added by epenthesis (and/or on the basis of a prosodic template)? Children lack sufficient evidence for deciding in favor of epenthesis or for assuming a final /e/ in the singular stem. As we will see later on, the fact that some children produce /e/ as the plural mark, before they master the production of final /s/ argues against an epenthesis analysis, as epenthesis only makes sense as a possible syllabification of an /s/ that otherwise would not be pronounceable (Saltarelli 1970, Harris 1986). For these children, final /e/ in the plural seems to be a morphological mark, not a mere epenthetic support introduced in order to avoid a coda. If that were the case, that is, if final [e] were due to avoiding a coda, it might also appear in the singular.

\subsection{Studies on the acquisition of plural formation, with special emphasis on Spanish}

Obviously, a question prior to the observation whether children have acquired the formal means to express plurality in a given language, concerns the very concept of plurality: is it an innate category or must it be learned? This question has been addressed in some studies, focusing on the acquisition of the English plural by very young children. In Wynn (1992) it is proposed that five-month-olds «possess some rudimentary appreciation of addition and subtraction». Apparently, as Bloom \& Wynn (1997: 512) have shown, children acquire the Fregeian meaning of number words «as predicates of sets of individuals» very soon, and they thus possess the ability to refer to plurality from very early on, as soon as it is conceptually needed. However, the specific meaning of number words is learned later on, on an individual and probably inductive basis, as the rest of the vocabulary is learned.

There have been several studies addressing the acquisition of the formal means to express plurality. Berko (1958) constitutes a classic study asking whether inflectional morphology (including nominal plural formation) in English is learned by means of rules or on a lexical piece-meal basis, and was in fact the first of its kind. Using pseudo-words (nouns and verbs) it tested some inflectional morphemes of English like the plural nominal allomorphs, the 3rd. pers. sg. verb endings, and the genitive 's on a population of pre-school and school children. It has been replicated in other languages, e.g. Pérez-Pereira (1989) applied Berko's methodology to Spanish inflectional morphology including plurals, diminutives, augmentatives, and some verbal morphology. There were four age groups in the Spanish study: 3-, 4-, 5-, and 6-year olds. As far as plurals are concerned, the suffix /-s/ was 100\% correctly produced with real words in all age groups, and for pseudo-words the values were also very high, increasing with age from $92 \%$ to $99 \%$. However, the suf- 
fix /-es/ received lower scores: 3 -year olds produced it $76 \%$ correctly with real words, and this score increased to almost $100 \%$ within the older groups. As regards pseudo-words, the values for the suffix /-es/ were low: $36 \%$ by the 3 -year-olds, $43 \%$ by the 4 -year-olds and $55 \%$ by the older group. Most of the errors consisted in substituting /-s/ for /-es/, or not adding anything, especially in the case of pseudo-words, which were apparently more difficult for the children than real words. This type of study is very valuable, but for the purposes we have in mind it is based on children that are already beyond the age when they begin to produce plurals. We would like to know when, how and in what sequence the expression of plurality is acquired in Spanish, and it is clear that 3-year-olds already have a long history of plural production behind them.

Marrero \& Aguirre (2003) focus on early acquisition of plural in Spanish, describing data from three children, aged $1 ; 7$ to $2 ; 0,1 ; 8$ to $3 ; 1$ and $2 ; 9$ to $4 ; 7$, respectively. They observe that plurality is first acquired in the noun, and that the first plural mark acquired is /-e/ for nouns ending in a consonant. Their interpretation of the data leads them to the conclusion that there are three phases in the acquisition of the plural in Spanish: 1) an initial premorphological stage, in which plural is not yet used, or used sporadically «in an unanalyzed way», 2) a «single marker» stage, at which only one of the words comprised in the plural phrase has the plural mark, and 3) a «markers extension» stage, at which plural generalizes to two (article + noun) or more places. At this stage, plural emerges in the verb, as well, and «agreement begins to be acquired» (Marrero \& Aguirre, 2003: 292). Their study addresses some of the central issues related to the acquisition of plural in Spanish, but leaves some loose ends, as for instance, do all Spanish children acquire plural in this proposed way? What is a premorphological stage? What is the status of the alleged «single marker» stage? Is there any relationship between acquisition of phonology and plural acquisition?

Lately, there have been some interesting studies on the first language acquisition of the German nominal plural, as e.g. Ewers (1999), Niedeggen-Bartke (1999) and Wegener (1995). In German there are at least eight plural allomorphs, -e, - er and $-\varnothing$ with or without umlaut, as well as $-s$, and the most common $-(e) n$; none of them are phonologically determined. Such varied and lexically determined allomorphy seems to be the reason why all studies report late learning of plural on the part of German children. This comparatively delayed acquisition (e.g. when compared wit the acquisition of plural by Spanish children) was already reported in earlier studies based on observation, as Park (1978), according to which plural morphology is not mastered by German children before 5 years of age. Similar results are found in Schaner-Wolles (1988), based on experimental data, although she did not use pseudo-words. Some studies on the acquisition of German plural try to experimentally find out whether on the basis of the endings there are associations between certain nouns in the singular and in the plural. They try to assess whether the lexicon contains schemata, as proposed by Köpcke $(1988,1998)$, according to which a continuum between singular and plural is characterized by certain endings, some of which qualify better as plurals (e.g. -(e)n) than other endings (-er or -el). 


\subsection{Research questions on the acquisition of plural and aims of the study}

The present paper aims at answering some of the basic questions posed by the acquisition of nominal plural in Spanish. As it has been discussed above, children seem to be able to distinguish individual objects from sets of objects, but they at first tend to refer to only single objects. A child shown a set with three items of an object $\mathrm{x}$ and asked «how many $\mathrm{x}$ are here?» will be able to answer with the plurality, e.g. he/she will say two or perhaps three. There is evidence from many reports on young children's performances that they might not know the names for «3», «4» or «5» yet (Bloom \& Wynn 1997), but they know that there are more than «one», and many children will just say $t w o$, independently of how many elements are contained in the reference set. There is thus a cognitive/semantic aspect of plurality, which seems to be mastered from the start, much before children use the correct number word and the correct plural ending(s). As argued above, there is a morphophonological side to nominal plurality, which in Spanish is relatively simple, but nevertheless requires some phonological precondition, i.e., the ability to produce final consonants (sg. pájaro 'bird'/pl. pájaros, sg. pez 'fish'/pl. peces). Finally, there is a morphosyntactic aspect to plurality, which in Spanish requires the redundant marking of all the words appearing in the NP or DP (sg. El niño bueno 'The good child'/pl. Los niños buenos). That is, the expression of plurality in the nominal constituents in Spanish requires three types of skills, or three types of knowledge, conceptual/semantic, morphophonological and morphosyntactic knowledge.

Having to acquire these three types of knowledge, or at least the last two that correspond to the form, the question must be posed whether the two sides of the formal knowledge are learned at the same time. When are they acquired, that is, when is the Plural acquired in Spanish? Is it first acquired in the noun and later on in the other constituents of the NP or DP? Or do determiners and adjectives appear with the plural marking from their first appearance on? Is Plural acquired on single nouns on a piece-meal fashion, or is there an underlying generalization about plural formation? What is the relationship between acquisition of Phonology and acquisition of Plural? And finally, we want to know whether bilinguals follow a different course of acquisition than monolinguals, that is: is the Spanish Plural acquired by monolinguals and bilinguals in the same way, and at the same time?

\section{Study on the Spanish nominal plural}

\subsection{Data and method}

In order to address these questions, spontaneous production data by three Spanish monolingual children, José $(1 ; 0$ - 2;6), María $(1 ; 0$ - 2;7), and Miguel $(1 ; 0$ - 3;0), as well as two Spanish-German bilingual children, Jens $(1 ; 2-2 ; 4)$ and Simon $(1 ; 1$ - 3;0), were scanned for nominal plurals; in the case of the bilinguals, only Spanish productions in Spanish sessions were considered. The monolingual data stem from the project PAIDUS and the bilingual data belong to the project E3 of the Collaborative Research Center on Multilingualism of the University of Hamburg, 
both directed by the author. All data consist of the spontaneous utterances produced by the children, who were audio- and video-recorded monthly in the case of the monolinguals, and fortnightly in the case of the bilinguals (after 2;0, monthly), from the beginning of word production through to $2 ; 6,2 ; 7$, and 3;0 (in the case of Miguel) or further (in the case of the bilinguals) ${ }^{2}$. The children were recorded in their homes in unstructured play situations, while interacting with their mothers and one investigator. The two languages of the bilinguals were kept apart in independent sessions, with two teams visiting the child, a German-speaking and a Spanish-speaking team. Following testing, all sessions were glossed and phonetically transcribed and all productions were entered into the Macintosh database 4thDimension.

For the purposes of the present study (Spanish) children's productions were considered in relation to the context, and when a plural noun was required by the context, the child's production was coded as to whether it had the necessary plural marking(s) or not. In diagrams $(1 \mathrm{a}-\mathrm{c})$ and $(3 \mathrm{a}, \mathrm{b})$ the number of contexts requiring plural obligatorily are entered in the legends as Obl(igatory) Plural and the number of plural nouns produced by the children are labeled Produced Pl(ural). If the noun was produced by the child with the corresponding article, determiner, or adjective, it was also noted whether these had the necessary plural marking(s). Because plurality is closely related to the production of final codas, the percentage of target final coda production by the corresponding child, previous to and during plural production, was also calculated; both, word final codas of stressed and unstressed syllables were calculated, whereas medial codas were not considered. For the purposes of this study, medial codas do not seem to be as relevant as final codas, as medial codas generally belong to a stressed syllable, whereas plural codas generally appear in unstressed syllables. Moreover, some Spanish children begin producing final codas before medial codas (that is the case for Miguel), whereas others (José and María) begin producing medial codas before final codas (see Lleó et al. 2003). As argued in Lleó (2003b), the licensing condition for medial codas is based on their belonging to a stressed syllable and on the linking of most coda consonants to the following onset. As none of these conditions are present in plural /-s/, a comparison of the development of medial codas and of plural /-s/ does not appear as useful. ${ }^{3}$ In order to trace a possible relationship between coda production and production of plural /-s/, the analysis of final codas excluded plural codas from the counts, i.e. the two categories were analyzed separately: on the one hand, plural /-s/ and on the other hand, final codas belonging to the lexical word. In order to find out whether production of plural /-s/ was related to the production of final [s] rather than to the production of final codas in general, because as put by one reviewer, [s] might be a difficult segment to acquire, one more measure was under-

2. Although as pointed out by one of the reviewers, it would have been advisable to look at data after those ages, especially in the case of José and María, the data sets stop at 2;6 for José and at 2;7 for María. Jens and Simon had been further recorded; however, the data were not yet available.

3. Two papers focusing on the acquisition of codas, namely Lleó (2003b) and Lleó et al. (2003) present word-final as well as word-medial coda production by this same population of children. 
taken: the development of plural /-s/ was compared to the development of other final [s] not belonging to the plural. ${ }^{4}$ This comparison is only reasonable if the child produces enough final [s] to be compared with. As this condition was not given in most children, whose final coda production was not very numerous, this analysis was only carried out in the case of Miguel (see figure 2d).

\subsection{Monolingual results}

Plural formation in nouns by the three monolingual children are shown in figures (1a) for José, (1b) for María, and (1c) for Miguel; these diagrams indicate the expected numbers of plural nouns ( $\mathrm{Obl}$. plurals) according to the target language (gray columns) and the real numbers of nouns produced with the plural marking by the respective child (black columns). The latter (Produced Pl.) refer to all recognizable productions of plural: /-s/ and /-e(s)/, including final [s] or not. Whereas José, and especially María, have very few cases of plural production, Miguel produces many plural nouns. José produces a few plurals beginning at 1;10. At 2;0 he produces 8 plural tokens, a relatively higher number than María's. Lack of plural production in María and José is not necessarily due to lack of obligatory contexts: although the number of contexts is not very high, as shown by the gray columns in the diagrams, there are many more than the child productions manifest. Miguel hardly produces any plurals until $1 ; 10$, but then within just one session he utters 19 tokens with a plural marking, corresponding to 16 noun types, most of which he had also produced in the singular up to that point.

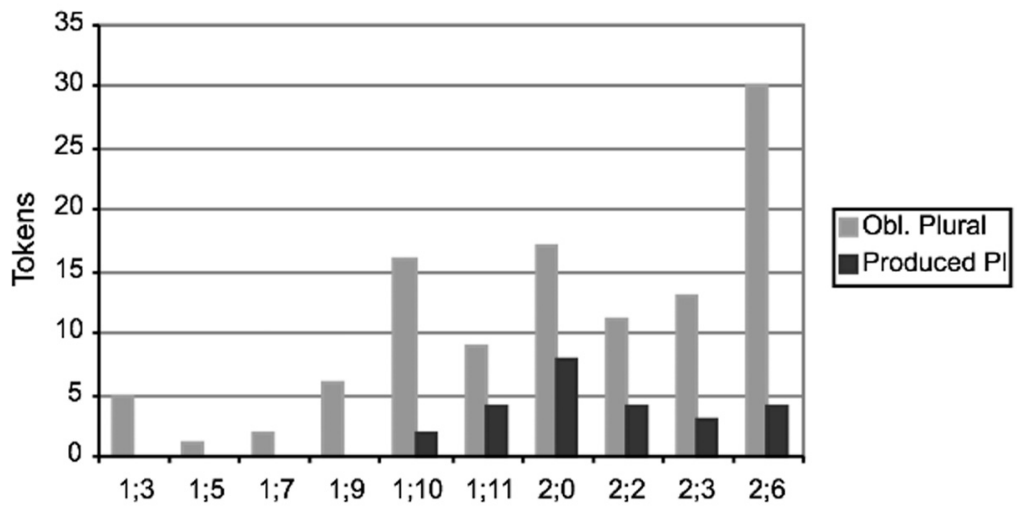

Figure 1a. Plural production (tokens) of nouns in plural contexts by José (monolingual).

4. For this analysis, [s] and [ $\theta]$ were counted together, as Spanish children tend to produce both sounds in the same way: they may produce both as [s] or both as [ $\theta]$, depending on the child and on the stage. 


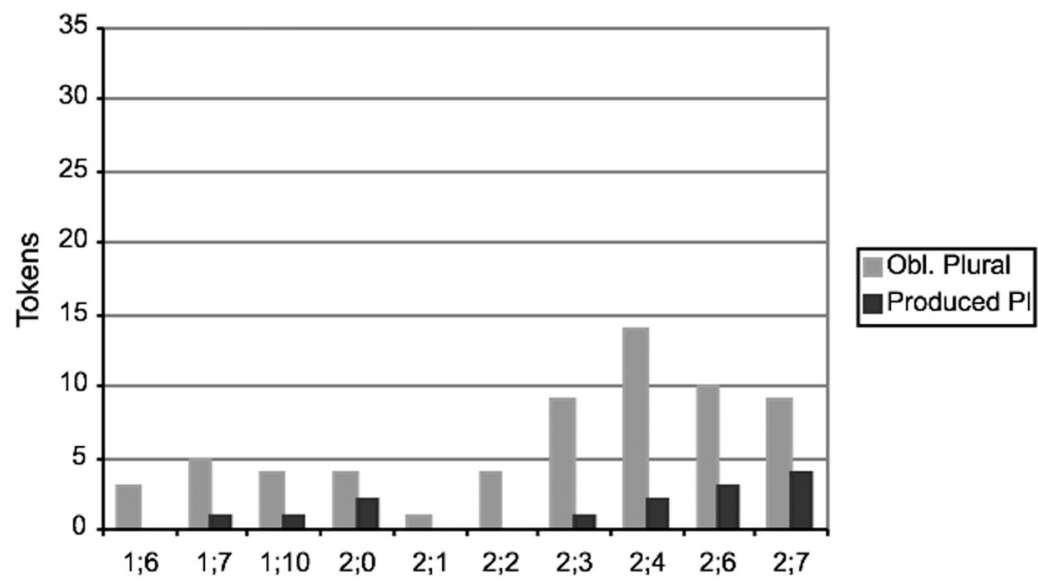

Figure 1b. Plural production (tokens) of nouns in plural contexts by María (monolingual).

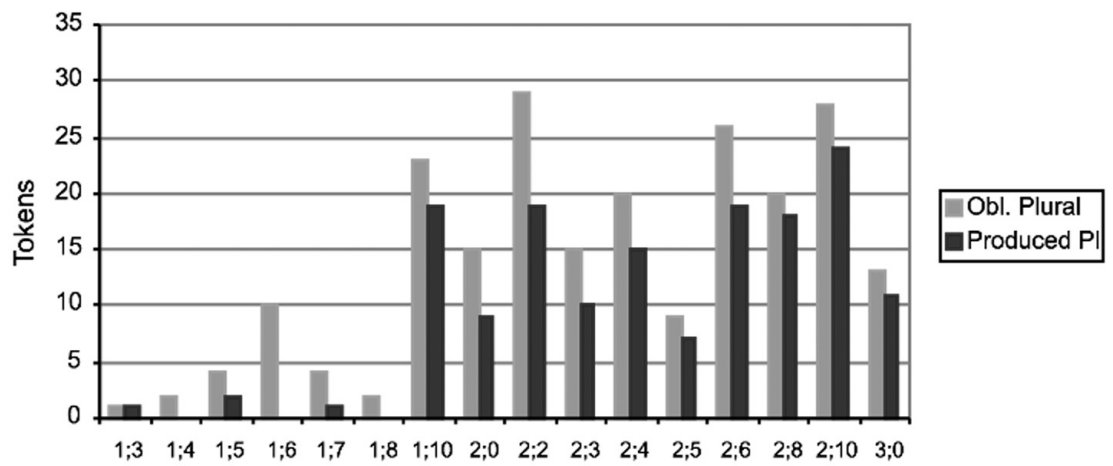

Figure 1c. Plural production (tokens) of nouns in plural contexts by Miguel (monolingual).

Table 3 shows in raw numbers whether the nouns produced in the plural by each child require the allomorph /-s/ or the allomorph /-es/; in the latter case, since as discussed above, there is double marking (by means of the vowel and by means of the consonant), if the vowel alone is present, the form has been counted as a plural, although in fact it only represents a type of incomplete plural, or proto-plural. Almost all cases of plural production by José are with the allomorph -e(s), generally produced without the final /-s/. That is, the percentage of nouns ending in a consonant that have a plural mark is much higher than the percentage of nouns ending in a vowel in José's productions. The few plurals produced by María correspond mainly to /-e(s)/ plurals, too, which she generally produces without the final /-s/, except in one case at 2;4. Whereas most plural markings in the case of 
Table 3. Number of /-s/ and /-es/ allomorphs (tokens) produced by the children from the beginning of Plural production.

\begin{tabular}{l|c|c|c|c|c|c|c|c|c|c}
\hline & \multicolumn{5}{|c}{ monolinguals } & \multicolumn{3}{c}{ bilinguals } \\
\hline children & \multicolumn{2}{|c|}{ José } & \multicolumn{2}{c|}{ María } & \multicolumn{2}{c|}{ Miguel } & \multicolumn{2}{c}{ Jens } & \multicolumn{2}{c}{ Simon } \\
\hline age & Pl. -s & -e(s) & Pl. -s & -e(s) & Pl. -s & -e(s) & Pl. -s & -e(s) & Pl. -s & -e(s) \\
\hline $1 ; 5$ & - & - & - & - & 0 & 2 & - & - & - & - \\
\hline $1 ; 6$ & - & - & - & - & 0 & 0 & - & - & - & - \\
\hline $1 ; 7$ & - & - & 0 & 1 & 0 & 1 & - & - & - & - \\
\hline $1 ; 8$ & - & - & - & - & 0 & 0 & - & - & - & - \\
\hline $1 ; 9$ & 0 & 0 & - & - & - & - & - & - & - & - \\
\hline $1 ; 10$ & 0 & 2 & 0 & 1 & 17 & 2 & 9 & 4 & 0 & 0 \\
\hline $1 ; 11$ & 0 & 4 & - & - & - & - & 13 & 5 & 1 & 0 \\
\hline $2 ; 0$ & 0 & 8 & 0 & 2 & 7 & 2 & 13 & 2 & 7 & 1 \\
\hline $2 ; 1$ & - & - & 0 & 0 & - & - & 1 & 1 & - & - \\
\hline $2 ; 2$ & 0 & 4 & 0 & 0 & 18 & 1 & - & - & 0 & 5 \\
\hline $2 ; 3$ & 1 & 3 & 0 & 1 & 9 & 1 & 5 & 2 & 7 & 3 \\
\hline $2 ; 4$ & - & - & 1 & 1 & 11 & 4 & 6 & 0 & 11 & 5 \\
\hline $2 ; 5$ & - & - & - & - & 4 & 3 & - & - & 12 & 0 \\
\hline $2 ; 6$ & 1 & 3 & 1 & 2 & 16 & 3 & & & 3 & 1 \\
\hline $2 ; 7$ & - & - & 0 & 4 & - & - & & & - & - \\
\hline $2 ; 8$ & - & - & - & - & 13 & 5 & & & 8 & 2 \\
\hline $2 ; 9$ & - & - & - & - & - & - & & & - & - \\
\hline $2 ; 10$ & - & - & - & - & 18 & 6 & & & 1 & 3 \\
\hline $3 ; 11$ & - & - & - & - & - & - & & & 11 & 1 \\
\hline & - & - & - & - & 10 & 1 & & & & \\
\hline
\end{tabular}

José and María are those that require the allomorph /-es/, Miguel's plural productions mainly correspond to /-s/ productions, /-e(s)/ representing a much smaller number. Miguel's results are in accordance with the input, because nouns ending in a vowel are much more numerous than those ending in a consonant in the child's lexicon. In the case of the allomorph /-es/ for nouns ending in a consonant, he produces it targetlike in $57 \%$ of the cases, and without the final /-s/ in the remaining $43 \%$.

Taking into consideration all plurals produced during the time span observed $(1 ; 0$ - 3;0), Miguel produces $75 \%$ of nouns ending in a vowel and eligible for plural formation with the allomorph /-s/, and $21 \%$ of the nouns ending in a consonant and thus requiring the allomorph /-es/. Although the numbers of nouns produced in the plural are very low at first, at $1 ; 10$ there is a sudden explosion of plurals produced: $83 \%$ of all obligatory plurals are already produced with a plural mark (generally with /-s/ and a few with /-e/ only). 
These results show thus two different patterns, one corresponding to José and María, with few plural markings, and a preference for the /-e/ marking in those nouns ending in a consonant, and the other one corresponding to Miguel, with a clear preference for the marking /-s/. These very different results raise the question of the relationship between production of final codas and plural marking on nouns. In Lleó (2003b) and Lleó et al. (2003) it was shown that Spanish monolingual children also show two patterns of coda production, Miguel producing a much higher percentage of target codas than José and María, who produced very few codas along the time span observed. Those studies did not separate codas as either belonging to the stem of a word or to the plural ending. Thus, in order to eventually be able to relate plural marking to the ability of a particular child to produce codas, the percentages of target codas produced as part of lexical items by each child (subtracting those codas that belonged to the plural) have been calculated and compared to the percentages of plural /-s/ markings (either /-s/ or /-es/ with final /-s/): the percentages of these measurements, stem codas and plural codas, are shown in figures (2a) for José, (2b) for María and (2c) for Miguel.

The diagrams show that Miguel is the Spanish monolingual child with the highest percentages of target coda production. Plural marking expressed by means of /-s/ begins at 1;10, after several months of coda production. Notice that the percentages of plural /-s/ production run relatively parallel to the percentages of nonplural codas, although both have been independently calculated, the latter being generally ahead, except for the ages 2;3 as well as 2;8 and 2;10. José and María have not reached sufficient percentages of coda production in order to begin yet to produce plural [-s]. Their percentages of plurals are very low, in fact similar to their percentages of codas.

Figure (2c) has shown a certain advantage of final coda production over plural /-s/ production for Miguel at most age points. As explained in the methodolo-

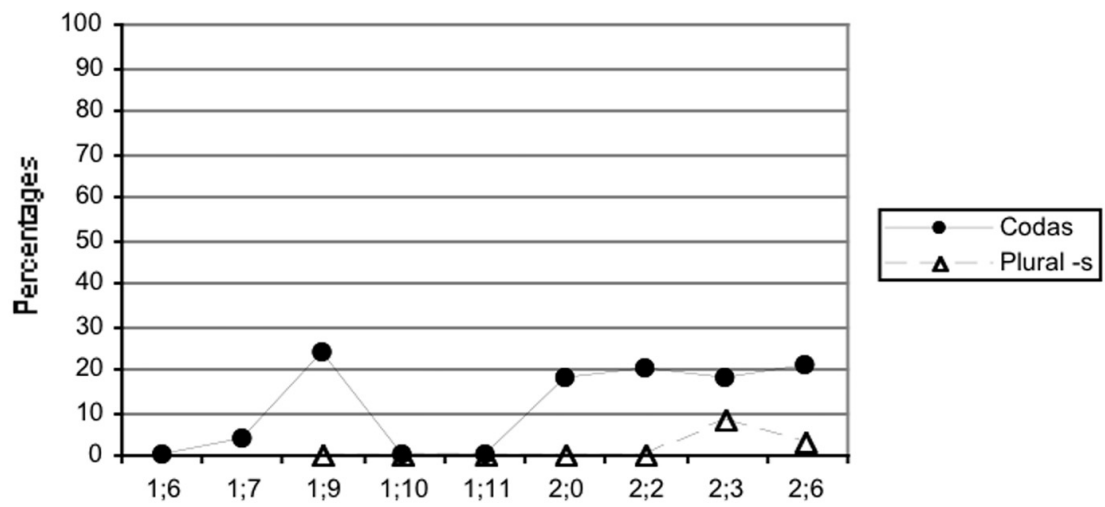

Figure 2a. Percentages of target coda production as compared to the production of Plural codas by José (monolingual). 


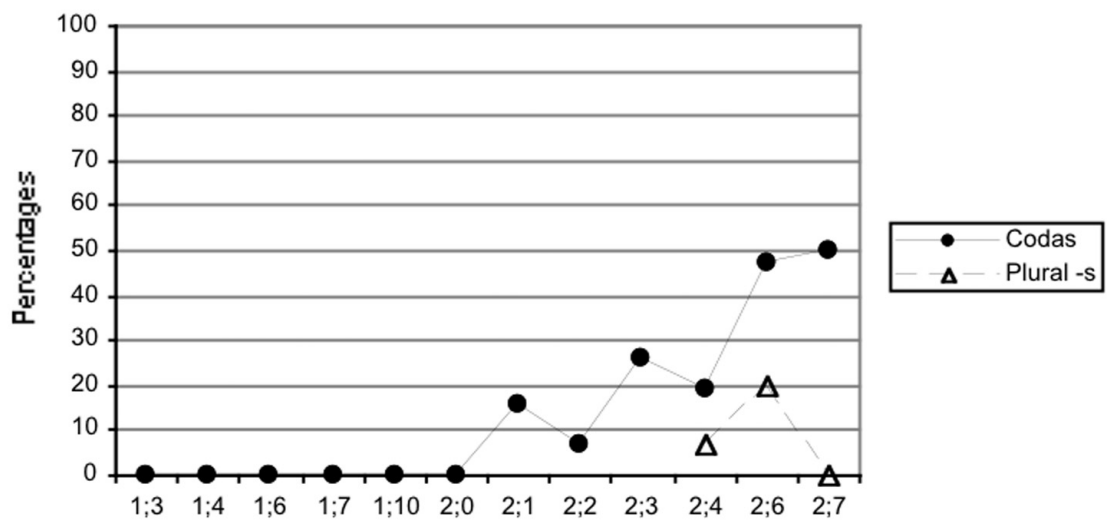

Figure 2b. Percentages of target coda production as compared to the production of Plural codas by María (monolingual).

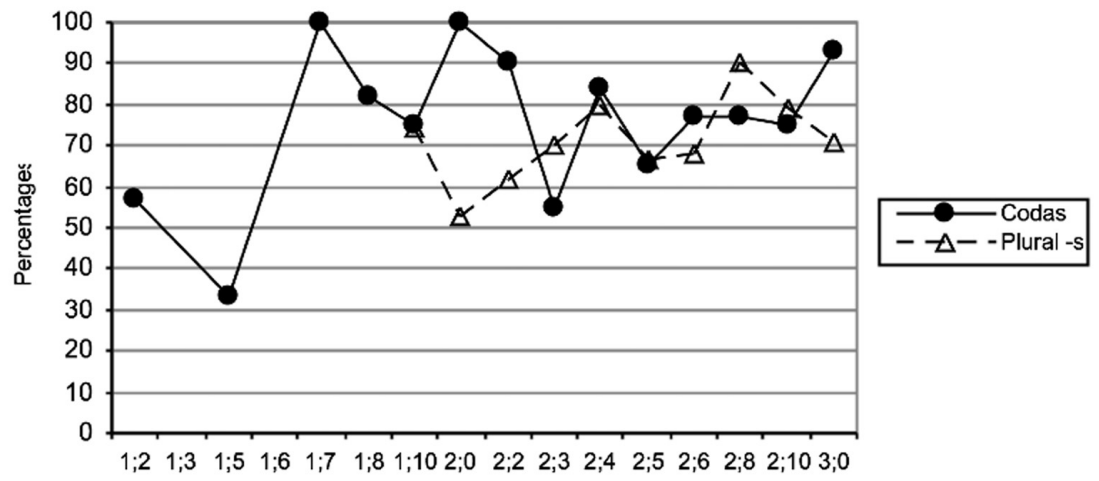

Figure 2c. Percentages of target coda production as compared to the production of Plural codas by Miguel (monolingual).

gy, a further comparison has been carried out in the case of Miguel, namely plural /-s/ with final [s] not belonging to the plural, but to the stem. Results are shown in figure (2d). This figure shows even more clearly than the previous one that plural endings emerge later than other codas. The curve for final non-plural [s] (and $[\theta]$ ) is at most points slightly higher than the curve for final codas (compare figures $2 \mathrm{c}$ and $2 \mathrm{~d}$ ), and higher than the curve corresponding to the production of plural $/-\mathrm{s} / 5$.

5. According to the data analyzed, [s] in the coda (finally or medially) does not seem to pose major difficulties to Spanish children, in the sense that it is acquired like other codas in general. The consonant which keeps the percentages of coda production lower is [r], which tends to be omitted until quite late in child Spanish. 


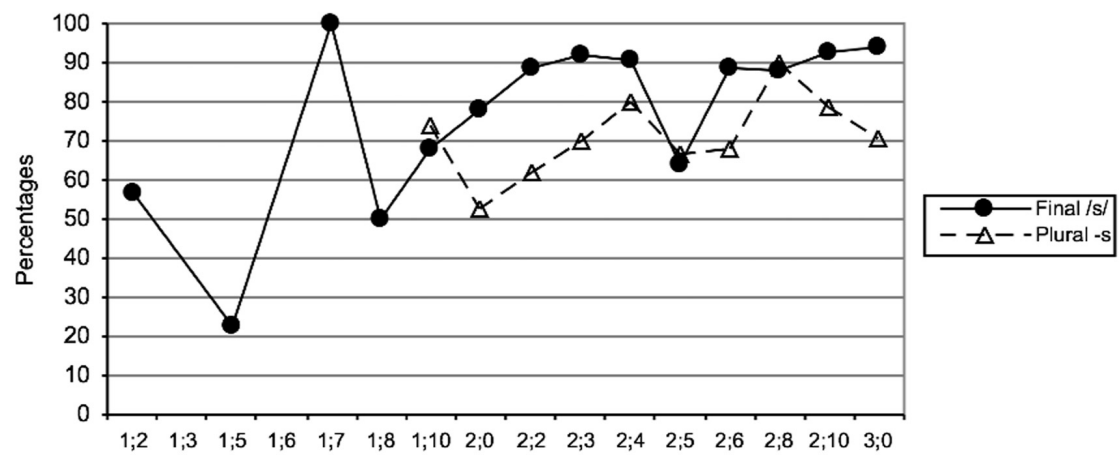

Figure 2d. Percentages of target coda /s/ production as compared to the production of Plural /-s/ by Miguel (monolingual).

\subsection{Bilingual results}

The results for plural production by the two bilingual children are shown in figures (3a) for Jens, and (3b) for Simon. The diagrams begin at 1;10, because before that age no contexts could be found, in which nouns should obligatorily appear in the plural. Jens begins at 1;10 to produce plural markings on nouns; although the numbers are not very high, the percentages reach very high scores. As in the case of Miguel, the majority of plural markings are in nouns ending in a vowel, the amount of /-es/ markings being much lower. Simon begins producing a fair number of purals later, from age 2;0 on. As in the case of Jens, Simon's plural markings are lower than Miguel's in absolute numbers, but higher in percentages, soon reaching $90 \%$ of all obligatory contexts. Although at first most of the plurals produced by Simon are plurals in /-s/ (see Table 3 above), later on he also has some plurals in /-es/; Simon produces almost always the final /s/ of both target allomorphs, /-s/ and /-es/ .

Figures $4 \mathrm{a}$ for Jens and $4 \mathrm{~b}$ for Simon record the percentages of coda production (again, excluding plural codas) for the respective child and compare these to the percentages of produced plural/-s/ markings (either/-s/ or /-es/ with final/-s/) out of the required ones, in a parallel manner as we did for the monolinguals. As in the case of the monolingual children, the curve for plural production begins later than coda production and runs relatively parallel to it. Jens reaches $100 \%$ of non-plural coda production soon (at 1;7), and his /-s/ plural markings reach $100 \%$ soon thereafter (at 1;11). Simon's non-plural coda production grows steadily after $1 ; 10$, reaching almost $80 \%$ at 2;0; at 2;2 the percentages of produced /-(e)s/ plural markings join the height of codas, and go very soon beyond that mark.

Summarizing the data on plural marking in nouns, there are two different main patterns, one for monolinguals and another one for bilinguals: 1) in the first place, bilinguals reach almost $100 \%$ of plural markings very soon, and reach almost $100 \%$ of /-s/ marking earlier than the monolinguals; their very high percentages of tar- 


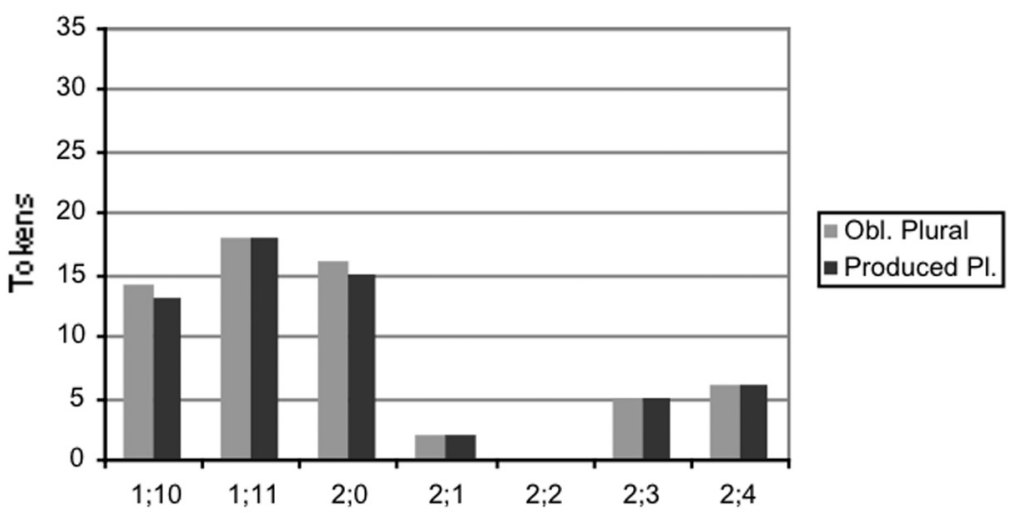

Figure 3a. Plural production (tokens) of nouns in plural contexts by Jens (bilingual).

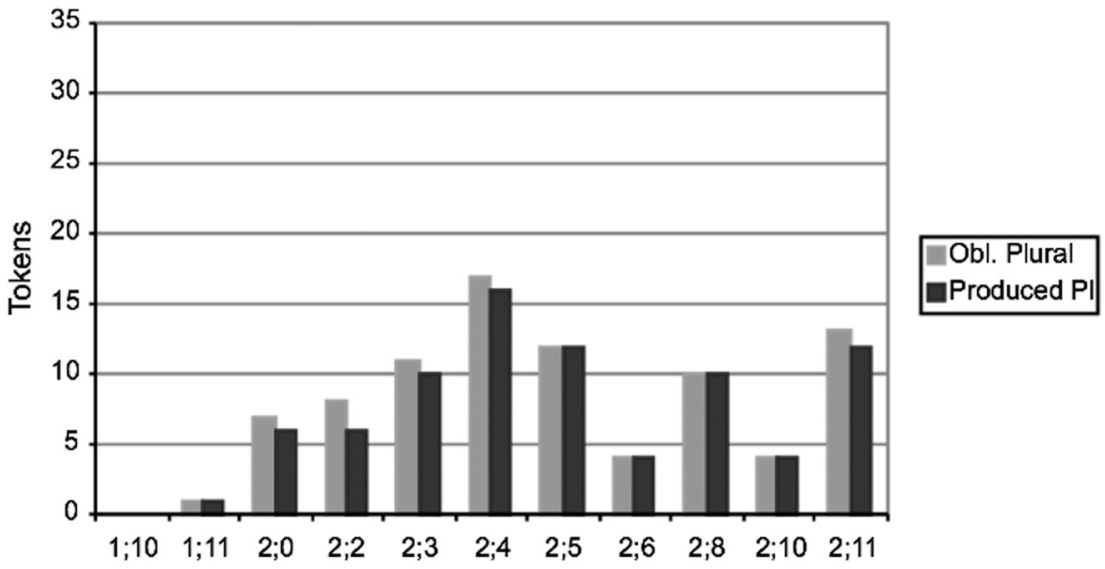

Figure 3b. Plural production (tokens) of nouns in plural contexts by Simon (bilingual).

get coda production in Spanish, higher than for any of the monolinguals, seems to play an important role in the acquisition of Plural. In the case of the monolinguals, there are in turn two different patterns, as well: 2) those children who do not produce final codas begin marking plurality only on nouns ending in a consonant, whereas 3 ) a child who produces a relatively high amount of codas (including [s] coda, as well) produces both, markings on stems ending in a vowel and on stems ending in a consonant, but prefers the former, as they correspond to the majority of words in his/her vocabulary. 


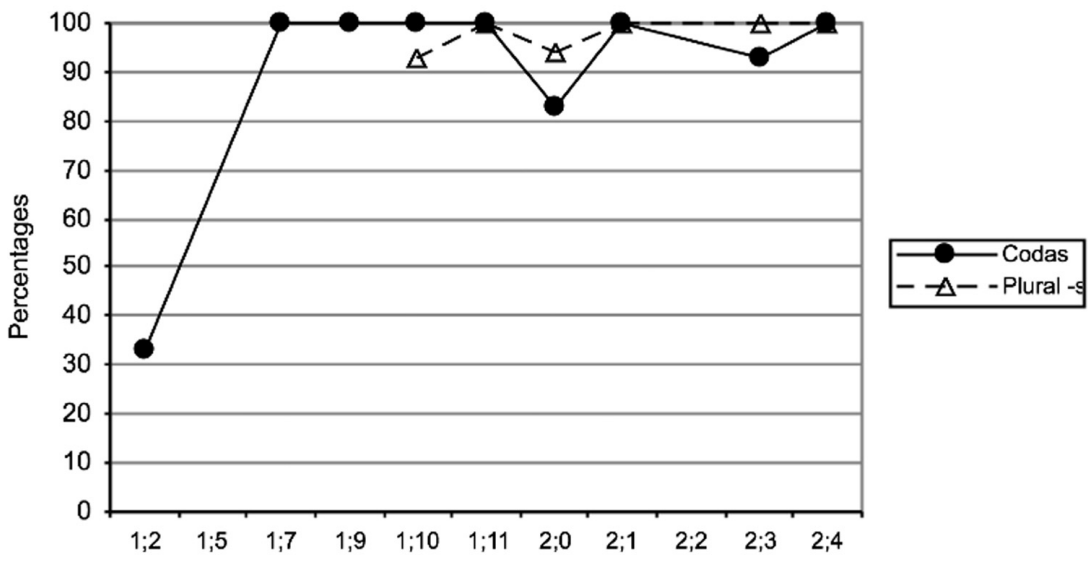

Figure 4a. Percentages of target coda production as compared to the production of Plural codas by Jens (bilingual).

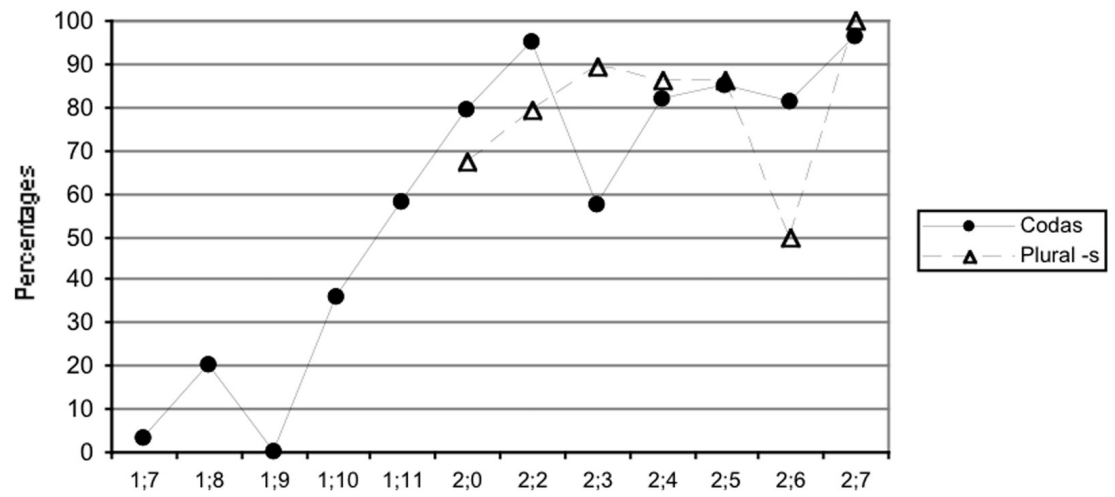

Figure 4b. Percentages of target coda production as compared to the production of Plural codas by Simon (bilingual).

\subsection{Plural Agreement}

Up to this point we have focused on plural formation of nouns. As shown in section 1.1, Spanish requires plural agreement for all words (determiners and adjectives) within the NP or DP. In this section we turn to agreement, i.e. to whether plural morphology is also expressed in determiners and adjectives. In the case of Miguel, after a stage in which most nouns appear in isolation, from about 2;0 on, he produces many nouns accompanied by an article, or by a quantifier. Adjectives appear, too, but they are not very numerous. Some of these data are shown in (3), where plural markings in the child's productions have been underlined: 
(3) Plural Agreement by Miguel: Determiner + Noun

\begin{tabular}{|c|c|c|c|}
\hline \multirow{8}{*}{$\begin{array}{l}\text { Miguel }(2 ; 0,20) \\
\text { Miguel }(2 ; 2,1)\end{array}$} & [los 'beðe] & los peces & 'the fish(pl.)' \\
\hline & [la ma'rai kes] & las margaritas & 'the daisies' \\
\hline & [les unes $\underline{s}$ & las uñas & 'the nails' \\
\hline & {$\left[\operatorname{los} \underline{s}^{\prime} \mathrm{d} \varepsilon \mathrm{s} \underline{\mathrm{s}}\right]$} & los dedos & 'the fingers' \\
\hline & [las 'nenes] & las nenas & 'the (little) girls' \\
\hline & [los 'djendes] & los dientes & 'the teeth' \\
\hline & [los ða'bados $]$ & los zapatos & 'the shoes' \\
\hline & [unos 'hrandes] & unos guantes & 'some gloves' \\
\hline Miguel $(2 ; 3,7)$ & [vojala'va lo 'plates] & voy a lavar los platos & $\begin{array}{l}\text { 'I'm going to wash } \\
\text { dishes' }\end{array}$ \\
\hline Miguel $(2 ; 5,21)$ & [mis oxes] & mis hojas & 'my leaves' \\
\hline \multirow[t]{2}{*}{ Miguel $(2 ; 6,17)$} & [los 'mostos] & los monstruos & 'the monsters' \\
\hline & ['esdo sun las 'manu] & esto son las manos & $\begin{array}{l}\text { 'these are the } \\
\text { hands' }\end{array}$ \\
\hline Miguel $(2 ; 8,14)$ & [?unaz 'vake] & unas vacas & 'some cows' \\
\hline
\end{tabular}

In the combination of Article + Noun, (3) shows that only in very few instances either the noun or the article lacks the plural marking. Between 1;10 and 3;0 there are 42 combinations of a noun in the plural preceded by the article: 29 articles $(69 \%)$ are marked with the plural ending and 13 articles (31\%) are not. Articles without final /-s/ appear all along the time span studied here. It is interesting to notice that nouns beginning with a vowel are always preceded by the plural /-s/ of the article, whereas those beginning in a consonant are sometimes lacking the plural /-s/. In the former case, the plural /-s/ is resyllabified as the onset of the initial syllable of the noun, whereas $100 \%$ of missing /-s/ markings are those that should appear before a consonant, and would have lead to the building of a cluster if pronounced (see Oellingrath 2003).

Some examples of plural quantifiers followed by a noun are shown in (4), where plural markings are again underlined:

(4) Plural Agreement: Quantifier + Noun

\begin{tabular}{|c|c|c|c|}
\hline Miguel $(2 ; 2,1)$ & [dus pa'jesos] & dos payasos & ‘two clowns' \\
\hline & [mahes 'gendo] & más cuentos & 'more stories' \\
\hline Miguel $(2 ; 4,3)$ & [dəç dosecre' $\chi$ Iðoç] & dos conejitos & 'two little rabbits' \\
\hline & [dos para'jitos] & dos pajaritos & 'two little birds' \\
\hline & [dos 'peses] & dos peces & 'two fish' \\
\hline & [doz 'pe $\theta \underline{\varepsilon s}]$ & dos peces & ‘two fish’ \\
\hline Miguel $(2 ; 4,26)$ & ['tres gone'xit ${ }^{\mathrm{h}} \underline{\mathrm{s}}$ ] & tres conejitos & 'three little rabbits' \\
\hline Miguel $(2 ; 10,9)$ & ['kato 'pata] & cuatro patas & 'four legs' \\
\hline
\end{tabular}

Numerals like dos 'two' or tres 'three' are produced in isolation until 2;0. At 2;2 Miguel begins combining dos with a noun, dos payasos 'two clowns', or with the article, los dos: in both cases he adds the final /-s/ of the plural to the noun and to the article, respectively. At 2;4 he produces four combinations of a noun preceded 
by dos 'two' and once a noun preceded by tres 'three': in these five cases, the noun has the final /-s/ of the plural. The sole exception, cuatro patas 'four legs', is produced at 2;10, not containing the final /-s/ of the plural patas 'legs'. We do not have further examples with the numerals cuatro 'four' or cinco 'five', which lacking the final /-s/ marker might suggest that the child is analyzing plural on the basis of prosody, i.e., as prosodic agreement, since dos and tres contain the final /-s/ marker, but cuatro and cinco do not. The data are scanty to confirm such an analysis.

Miguel uses some nouns and adjectives with a predicative function, generally after the verb ser 'to be'. Some examples are shown in (5):

\begin{tabular}{|c|c|c|c|}
\hline & [sun 'lo:s] & son loros & ‘(they) are parrots’ \\
\hline & [son les 'nenes] & son las nenas & '(they) are the girls' \\
\hline & [son $\theta l$ e'visbe] & son las avispas & '(they) are the wasps' \\
\hline \multirow{4}{*}{ Miguel $(2 ; 4,26)$} & ['søn go'ncho] & son conejos & '(they) are rabbits’ \\
\hline & ['zon 'mios] & son míos & '(they) are mine’ \\
\hline & ['zon ma'dunes] & son marrones & '(they) are brown' \\
\hline & ['son Pama'rijos] & son amarillos & '(they) are yellow' \\
\hline Miguel $(2 ; 6,17)$ & 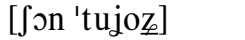 & son tuyos & ‘(they) are yours’ \\
\hline
\end{tabular}

As far as adjectives are concerned, between 2;4 and 2;10 Miguel uses five adjective types in the plural, marrones 'brown', verdes 'green', negros 'black', amarillos 'yellow', malitos 'sick'. All these adjectives have previously been produced in the singular form. It is important to notice that not a single utterance of these adjectives in the plural lacks final/-s/ including marrones, which has the singular form ending in a consonant, marrón. It is clear that Miguel has already acquired plural agreement in Spanish.

José's early plural productions do not generally contain final /-s/ (see section 2.2). At 2;0 he begins combining plural nouns with a preceding article, whose form, because of the vowel, can generally be interpreted as a plural in spite of lacking final /-s/, as in [lo] for los and [uno] for $\operatorname{unos}^{6}$ (see Table 1 above). Examples of such utterances, recognizable as plurals because of the vowel, but based on a still non-target-like plural marking, are given in (6):

6. In Lleó (2003b: 275) I pointed out that José goes through a stage at which he substitutes uno for un, when the article is preceding a masculine singular, and that this substitution has been reported for other Spanish children in the literature. Although such a substitution might respond to some children's preference for analyzing the article as a constituent of the PPh, and thus to produce it as a disyllabic word (instead of an unfooted syllable to the PW), as I argued there for José and in Lleó (2003a) for Miguel, such data may be ambiguous in contexts allowing for plurality, and some of them should be reconsidered under the perspective of incomplete plural formation, i.e., under the alternative of them representing plurals lacking /-s/. 
(6) Plural Agreement by José: Determiner + Noun

\begin{tabular}{|c|c|c|c|}
\hline José $(2 ; 0,3)$ & 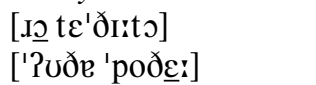 & $\begin{array}{l}\text { los cerditos } \\
\text { unas flores }\end{array}$ & $\begin{array}{l}\text { 'the piggies' } \\
\text { 'some flowers' }\end{array}$ \\
\hline \multirow[t]{5}{*}{ José $(2 ; 2,16)$} & [lo pa'ßajo] & los caballos & 'the horses' \\
\hline & [?uno pape $\varepsilon^{\prime t} \sin \varepsilon$ ] & unos calcetines & ‘some socks' \\
\hline & [uno mo'tone] & unos botones & 'some buttons' \\
\hline & [nㅡํ phe'pape] & los/unos elefantes & $\begin{array}{l}\text { 'the/some } \\
\text { elephants' }\end{array}$ \\
\hline & [ํㅡ ze'rit’] & los cerditos & 'the piggies' \\
\hline \multirow[t]{2}{*}{ José $(2 ; 3,29)$} & ['Puñ pa $^{\mathrm{j} I} \mathrm{melo}$ 'mijo] & unos caramelos míos & $\begin{array}{l}\text { 'some of my } \\
\text { candies' }\end{array}$ \\
\hline & [l’ 'tijo] & los tíos & 'the uncles/aunts' \\
\hline \multirow[t]{6}{*}{ José $(2 ; 6,12)$} & [lō ga'gat:o: $]$ & los lagartos & 'the lizzards' \\
\hline & [ðe lo $\underline{\mathrm{h}}^{\mathrm{h}}$ фeðe'pate] & de los elefantes & 'of the elephants' \\
\hline & [loh pe:] & los peces & 'the fish(pl.)' \\
\hline & [a lo 'paxaðo:] & a los pájaros & 'to the birds' \\
\hline & ['uno tel'dito:] & unos cerditos & ‘some piggies' \\
\hline & ['una 'ðоßо:] & unos globos & 'some balloons' \\
\hline But & [lo.s ani'maðe: ] & los animales & 'the animals' \\
\hline
\end{tabular}

Notice that nouns beginning with a vowel, like the last one, animales 'animals', prosodically license the plural marking in the article: animales is preceded by los, where the /-s/ is resyllabified as the onset of the first syllable of the noun. This process has also been noticed for Miguel above; it explains the only case of plural marking expressed in the article in José's data. Otherwise, there are no [-s] markings, neither on the noun nor on the Determiner. Nouns preceded by a plural quantifier are never marked for plurality, as the examples in (7) show:

\section{(7) Plural Agreement: Quantifier + Noun}

$\begin{array}{llll}\text { José }(2 ; 3,29) & \text { [haI 'do na'tito] } & \text { hay dos gatitos } & \text { 'there are two kitties' } \\ \text { José }(2 ; 6,12) & \text { [ðo 'paxaðo] } & \text { dos pájaros } & \text { 'two birds' } \\ & \text { [lo ðo 'paxaðo: }] & \text { los dos pájaros } & \text { 'the two birds' }\end{array}$

Numerals were already produced at 2;0, but only in isolation, as an answer to the interviewer's question: ¿Cuántos cerditos hay aquí? 'How many piggies are there?' or ¿Cuántos gatitos hay aquí? 'How many kitties are there?'. From the context it is obvious that there are 'three' piggies and 'nine' kitties, but José answers $d o(s)$ 'two' in both cases, showing that for him, dos 'two' means plurality. He clearly uses the masc. sing. un 'a/one' for the singular, which he opposes to dos 'two' for plurality. But there is no [-s] marking here either, neither on the noun nor on the numeral.

As far as the two bilingual children are concerned, we have seen that they produce plural marking in the noun from the first intended plurals on. Jens shows a few cases of plural agreement, too. In his productions there are not many contexts 
in which agreement is necessary. But when required, the child generally produces it, as shown in a few examples in (8) for a compound (marked with plurality at the end, not in the head, as required by the target language), and coordinated nouns, in (9) for quantifier + plural noun and in (10) for article + noun, noun + adjective, and a combination of the three (article + noun + adjective), where all plural markings are present.

(8) Plural Agreement: Nouns, Compounds Jens $(1 ; 11,14) \quad$ ['o.so]['pan.das: $]$ Jens $(2 ; 4,27) \quad$ ['pa.las][i]['ku.ßos]

$\begin{array}{ll}\text { osos panda } & \text { 'panda bears' } \\ \text { palas y cubos } & \begin{array}{c}\text { 'shovels and } \\ \text { buckets' }\end{array}\end{array}$

(9) Quantifier + Noun

Jens $(2 ; 3,15) \quad$ [dos][pa.'ja.sơs] [dos]['to.res]

(10) Plural Agreement: Art + Noun + Adjective

\begin{tabular}{|c|c|c|c|}
\hline Jens $(2 ; 3,30)$ & [les]['plo.to.nos] & los plátanos & 'the bananas' \\
\hline Jens $(2 ; 3,15)$ & [ka.'ßa.jos] ${ }^{\top}[$ 'ne्..yos] & caballos negros & 'black horses' \\
\hline & [i][los][ka.'ßa.jos]]['blan.kos] & $\begin{array}{l}\text { y los caballos } \\
\text { blancos }\end{array}$ & $\begin{array}{l}\text { 'and the } \\
\text { white horses' }\end{array}$ \\
\hline
\end{tabular}

$\begin{array}{ll}\text { dos payasos } & \text { 'two clowns' } \\ \text { dos torres } & \text { 'two towers' }\end{array}$

In the case of Simon, the first combinations with quantifiers and with demonstratives appear at 2;2 and do not always have the plural marking on the noun: $d o s$, tres, cuatro jirafa(s) 'two, three, four giraffes' and estos papel(es) 'these pieces of paper'. At 2;3 he already produces plural agreement in estos coches 'these cars' and dos mariposas 'two butterflies' (some examples are shown in (11)), and from then on agreement is general. However, when the plural noun should be preceded by an article, the latter takes an unspecified form, in fact, what we have elsewhere called a protoarticle (see e.g. Lleó 2003a), without any plural marking on it (see examples in (12)). It is important to notice that Simon produced many protoarticles or so-called fillers, just represented by a vowel like [a] or similar, for a long period of time. At 2;4, at the same time at which he produces e.g. muchos coches 'many cars', both words with the plural /-s/, he produces lo $(s)$ juguete(s) 'the toys' without $/ \mathrm{s} /$ in the article nor in the noun, and the lack of plural marking in the article lasts for some time. At 2;6 he produces the /-s/ of the plural article for the first time in las estrellas 'the stars' and from this point on, he correctly produces plural articles. 
(11) Plural Agreement: Quantifier + Noun

Simon $(2 ; 2,19)$ [dos tes kato fi'afa] dos, tres, cuatro jirafas 'two, three, four giraffes'

$\begin{array}{llll}\text { Simon }(2 ; 3,18) & {[\text { dos ea pi'posas] }} & \text { dos mariposas } & \text { 'two butterflies' } \\ & \text { ['kuato 'Oinko jei] } & \text { cuatro, cinco, seis: } & \text { 'four, five six:' } \\ & \text { [dos pi'posas] } & \text { dos mariposas } & \text { 'two butterflies' }\end{array}$

Simon $(2 ; 4,1) \quad$ [?e 'kuento ?e dos el cuento de (los) dos pingüinos wi'winos] 'the story of the two pinguins' ['mut fos dos tes muchos: dos, tres, dos peces dos 'pe日es] 'many: two, three, two fish(pl.)' [dos 'pe日es] dospeces 'two fish' [dot 'anos] dos años 'two years'

Simon $(2 ; 4,15)$ ['mudjos 'mudjos muchos, muchos coches 'kot [es] 'many, many cars' [dos koto'toðas] dos locomotoras 'two locks' [dos 'pe $\theta$ es] dos peces 'two fish'

(12) Plural Agreement: Determiner + Noun

\begin{tabular}{|c|c|c|}
\hline Simon $(2 ; 0,11)$ & [le’ 'liklo] & los libros \\
\hline Simon $(2 ; 2,19)$ & ['eto $\underline{\theta} \underline{\text { mi'males}}]$ & estos animales \\
\hline & ['etos 'papel] & estos papeles \\
\hline Simon $(2 ; 3,4)$ & ['etos 'kot $\left.\int e \underline{s}\right]$ & estos coches \\
\hline & [a.a o $\left.{ }^{h} e^{h} \cdot h a \underline{s}\right]$ & las orejas \\
\hline Simon $(2 ; 4,1)$ & [go $\chi \mho^{\prime}$ hete] & los juguetes \\
\hline Simon $(2 ; 5,13)$ & [a xu'ya la 'kot $\int e \underline{\text { ] }}$ & a jugar con los coches \\
\hline Simon $(2 ; 5,27)$ & $\begin{array}{l}\text { [a 'musika e lo } \\
\text { pap'ja日os] }\end{array}$ & $\begin{array}{l}\text { la música de los payasos } \\
\text { 'the music of the clowns' }\end{array}$ \\
\hline
\end{tabular}

'the books' 'these animals' 'these pieces of paper' 'these cars' 'the ears' 'the toys' 'to play with the cars'

The few adjectives appearing before 2;10 do not agree with the noun in plurality, that is, the adjectives do not bear any plural mark, as shown in (13). Obviously, Simon has not acquired plural agreement with adjectives before 2;10.

(13) Plural Agreement: Predicative Noun + Adjective

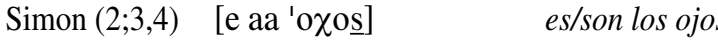

'(these) are eyes'

Simon $(2 ; 5,13)$ ['eto $\underline{\theta}$ ta'mbie 'nande] estos también grandes 'these big too' ['etos tren 'nande] estos trenes grandes 'these big trains'

Simon $(2 ; 10,2)$ ['tengo mas 'roxios] tengo más rojos 'I have more red ones' 


\subsection{The special status of unfooted syllables}

As we have seen, before 2;6 the article does not agree with the plural noun in Simon's data. There is a clear relationship between lack of plural marking in the determiner, as shown in some of the examples in (11) - (13), and the extensive use that this child makes of protoarticles, i.e. fillers preceding nouns. In order to understand the special status of determiners and their consequences in the case of this particular child, it is important to notice that in the target language most of the articles (the monosyllabic ones) constitute an unfooted syllable. Lleó (2002) shows that German children tend to truncate the unfooted syllables of Prosodic Words, much more often than Spanish children do, but that some Spanish-German bilinguals truncate unfooted syllables in Spanish to the level that German monolinguals do. This is the case for Simon, who had high percentages of unfooted syllable truncation in Spanish. Moreover, Lleó (2003a) shows that unfooted syllables corresponding to the articles are produced relatively soon by all Spanish monolingual children and some bilinguals, too. As Fig. 5 shows, Simon produces high percentages of fillers until a relatively advanced age: at 2;2, his fillers still reach almost $100 \%$ in contexts, in which an article would be necessary. Obviously, such a weak and unspecified syllable is not suited to express plurality, or even gender. What is more crucial: in Lleó (2003a, 2003b) I have postulated that, whereas children like Miguel soon analyze the article + noun as a PPh, other children, like Simon, dwell longer on an analysis of article + noun as a simple PW. This can explain the lack of agreement in the article, kept by Simon for quite a long time, i.e., plural marking is allowed only once within the Prosodic Word. If the child analyzes the article as belonging to the $\mathrm{PW}$, no plural mark is allowed on the article, as otherwise there would be double marking on the PW. But once the child is able to represent the

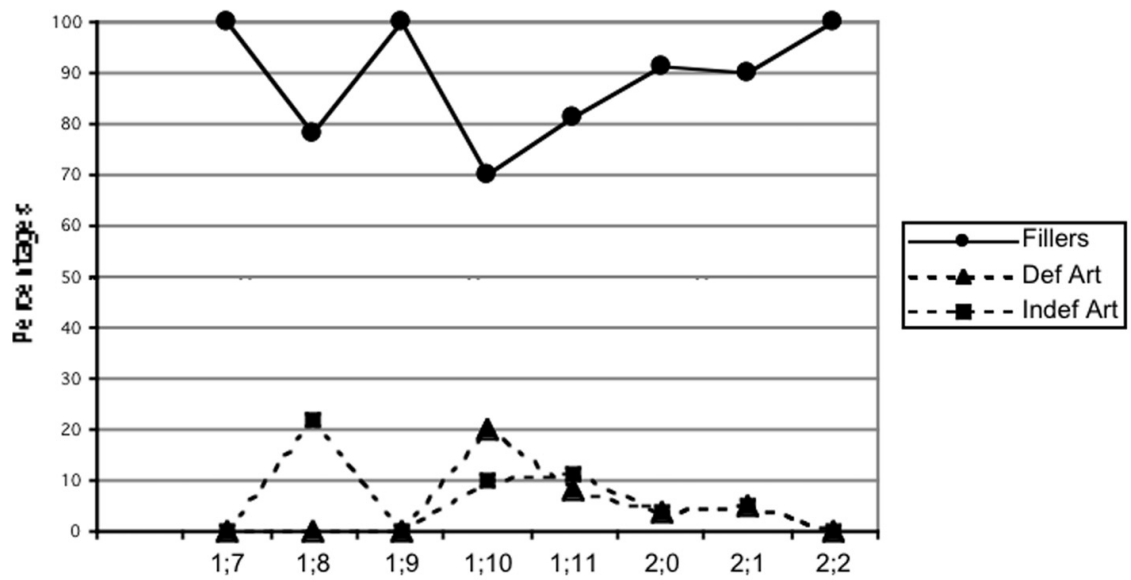

Figure 5. Percentages of default fillers as compared with full articles produced by Simon (bilingual). 
article as being adjoined to the $\mathrm{PPh}$, the article can bear the plural ending, too. This, again, makes clear that prosody conditions morphology, i.e., the acquisition of morphology depends on how advanced the child is in his prosodic development.

\section{Discussion}

Miguel has a very high percentage of correct plural production beginning at 1;10, with only a few cases of missing /s/ from the plural allomorph added to nouns ending in a consonant. Once he begins combining plural nouns with articles at 2;0, both noun and article bear the plural morpheme. When he begins combining plural nouns with numerals at 2;2, the noun bears the plural morpheme, too. Adjectives bear the plural morpheme, as required. Miguel has a very high percentage of coda production for a Spanish child, and this allows him to produce the plural endings from the very beginning of plural production. In the case of José and María, who as shown in Lleó (2003b) and here confirmed, produce a very low percentage of target codas, there appear almost no plural marks in the obligatory contexts. Interestingly, though, at first most of their plural productions correspond to nouns ending in a consonant. This is especially clear in the case of José. That is, these children «know» plurality and «know» how their language expresses plurality, but they lack the prosodic basis to produce plurality in an adequate manner. The prosodic constraints of their grammar (lack of codas) prevent them from producing morphology correctly. José, who has a slightly higher production of plurals than María, also shows some combinations of determiner plus noun. In all cases, the /s/ is missing. Plurality is interpretable because of the (incomplete) form of the article, like $l o(s)$ or $u n o(s)$ or because of the numeral $d o(s)$. In the case of the bilingual children, Jens begins producing plurals at about the same age as Miguel. Simon begins producing spontaneous plurals at 2;0; both children soon reach almost $100 \%$ of plural production in nouns. We had noted in previous studies (see Lleó et al. 2003) that bilinguals tend to produce high percentages of target codas from early on, higher than Spanish monolinguals. Bilinguals thus reach a very high percentage of plural /-s/ production, because they have the prosodic means for producing the necessary codas. However, Simon's most striking phenomenon consists in the production of some cases of plural nouns preceded by a protoarticle, without any plural marking on it. Articles constitute proclitic entities in Spanish, which have prosodically been characterized as unfooted syllables. Simon has been shown to have a long lasting tendency to truncate unfooted syllables of lexical items, which as suggested in Lleó (2002) may result from the interaction with German, and this is manifested in the production of early articles as defaults, which in turn influences the acquisition of plurality: he is prepared to agree nouns and other elements like demonstratives, numerals or quantifiers in plurality, but not the definite article. Demonstratives like estos 'these' being disyllabic constitute a Foot and are analyzed as part of the $\mathrm{PPh}$, whereas monosyllabic articles, like los or las 'the', are analyzed as part of the PW, and only one plural mark is allowed in one PW, namely on the noun. This points again to the prosodic conditioning of morphology: prosodic constraints limit the acquisition of morphology. 
Our data have shown that all children begin producing final codas of lexical items before producing plural codas. This poses two questions. On the one hand, lexical codas are segmentally more varied, including the nasal $/ \mathrm{n} /$, the lateral $/ 1 /$, the vibrant $/ \mathrm{r} /$, and the palatal glide $/ \mathrm{j} /$, beside the fricatives $/ \mathrm{s} /$ and $/ \theta /$, whereas plural codas are always /-s/. It could thus be objected to this alleged advantage of lexical over plural codas that it is due to the well-known fact (since Jakobson 1941) that fricatives are relatively difficult sounds. More concretely, fricatives like [s] seem to pose difficulties to children acquiring English (see Smith 1973, Velleman 1988, Vihman 1996). We have thus separated lexical coda fricatives ([s] and $[\theta]$ ) from all other codas for the monolingual child, Miguel, who had high numbers of codas. The results, mapped onto figure (2d), have shown that it is not the case that for this particular child fricatives pose any special problem, as the curve for the coda /s/ (belonging to the lexical stem) exhibits slightly higher percentages than the one for lexical codas in general. Spanish children do not seem to have difficulties with fricatives, strident or otherwise (see Rakow \& Lleó 2003, where it is shown that spirants are also acquired very soon in Spanish); the most difficult coda for them is /r/. It cannot thus be argued that plural /-s/ comes in later than other codas, because [s] is specially difficult as a coda.

On the other hand, our results appear to be very different from those obtained by Freitas et al. (2000) for Portuguese, as they argue that plural codas are acquired earlier than other codas. In fact, it is difficult to judge whether their results are as different from ours as it might seem at first glance, as they do not quantify the data. Their results are only illustrated by examples, many of which show a very close development, as for instance final lexical fricatives in comparison to plural fricatives. In order to be able to interpret such results as showing a more advanced development of plural codas over other codas, percentages should be calculated and compared. In spite of the appearance of plural codas as more numerous, the percentages of plural coda production might in fact be lower than the percentages of lexical coda production. In case they are not, that is, if the percentages of plural codas produced are indeed higher than the percentages of lexical codas, we should search the reason somewhere else. One possible source of differences between the Portuguese and the Spanish child data may lie in the fact that Portuguese has less lexical codas than Spanish, because many of the early codas in Spanish are represented by the nasal $[\mathrm{n}]^{7}$, whereas in Portuguese nasals are not produced in the coda, but as nasalization on the previous vowel. Thus Spanish children may get more experience with lexical codas than with plural codas, which might explain that lexical codas take the lead over plural ones.

Let us now turn to the questions posed above, in section 1.3. Do Spanish children learn plural in a systematic way or in a piece-meal fashion? Miguel's development supports the hypothesis that Plural is acquired on the basis of a general statement or rule of Plural formation: the burst of about 20 plural nouns in one single session, as experienced by Miguel at 1;10, makes it difficult to imagine that all

7. Many words of the early lexica end in a nasal, as e.g. tren 'train', pan 'bread', camión 'truck', ratón 'mouse', también 'too', etc. 
these plural forms are saved in the lexicon independently of their singular forms, in a piece-meal fashion. However, when considering the slow development experienced by José and María, one could be tempted to posit individual differences, i.e., a child like Miguel acquires Plural by means of a rule, José and María develop Plural in a piece-meal fashion. We do not have further data on these two children that would allow us to trace a possible future relation between coda acquisition and further development of plural markings. However, on the basis of the evidence provided by Miguel and by the two bilinguals, it seems that it is not warranted to consider that acquisition of the nominal Plural takes place on a piece-meal fashion. It is plausible to advance the hypothesis that once the prosodic means (i.e. codas) are available, Plural is acquired fast and targetlike, for all nouns at once, so to say.

Clearly, not all children begin producing plurals at the same age, some begin earlier than others. But all children show a clear dependency of morphological markings on phonological constraints. Those children that develop codas faster, like the bilinguals do, are soon able to produce plural markings targetlike, whereas children who are relatively slow in coda mastery are late in plural/-s/ production, as well. However, they are able to express plurality before the prosodic skill has been acquired. This shows that it is not reasonable to propose a premorphological stage: forms may not yet be produced targetlike, but the child manages to express plurality on the prosodically «easy» nouns, those that end in a consonant, although they are in the minority. Our data do not support a «single marker» stage, as postulated by Marrero \& Aguirre (2003). This may just be an artifact of an incomplete prosody: at first, when plural is expressed by some of the children by the vowel -e, no other plural markings are present, because the child cannot produce final /-s/ yet, but as soon as /-s/ is available, it appears on most of the constituents, as required by Agreement. The sole exceptions to this statement are the missing plural markings in Simon's articles before 2;6, due to this child's default phonological shape for the unfooted syllable of the article. This means that the «single marks» are just a by-product of defective coda production or the result of a prosodic analysis, in which the monosyllabic protoarticle is part of PW, not of PPh.

Pérez-Pereira (1989) has shown that Spanish children have more difficulties building the plural with /-es/ than the plural with /-s/. The Spanish children of our study begin very soon to produce the plural with /-e(s)/, relatively sooner than the plural with /-s/, although they often leave the /s/ unpronounced, especially in the case of José and María. This is not the case for the bilinguals, who are very skilled with coda production. It may well be that in an experimental situation, especially with pseudo-words, children experience many more difficulties with the /-es/ allomorph. This does not seem to be the case from a developmental perspective, as also shown by Marrero \& Aguirre (2003). In fact, our results are neutral as far as what allomorph is acquired first: depending on the prosodic means available (whether the child has already acquired codas or not), Plural will be first expressed in the nouns ending in a vowel (the most numerous in the vocabulary) or in the nouns ending in a consonant (in spite of the fact that these are much less numerous). It is interesting that the 3- and 4-years-old studied by Pérez-Pereira (1989) tended to substitute /-s/ for /-es/, whereas the children of our study tended to only produce 
/-e/. On the basis of Pérez-Pereira's result one could argue in favor of the epenthesis analysis (see section 1.2), as they apply the sole morph /-s/ and have not yet learned that Spanish needs an epenthetic vowel. On the basis of our data, there is no justification for epenthesis, as children at first produce /-e/ as the sole plural morph. That is, they produce the target vowel, not as epenthetic, but as a morphological marker. This suggests a very interesting result: children may concentrate on morphology first, i.e., on expressing meaning, but they are limited by their phonological capabilities. The development we observe for Plural Formation in Spanish comprises thus three stages:

\section{(14) Stage $1 /$-e/ $\rightarrow$ Stage $2 /$-s/ $\rightarrow$ Stage $3 /$-(e)s/}

Stage 1 is represented mainly by children like José and María, who do not yet have codas available. Stage 2 is arrived at by all children, for some--at about 3;0 and 4;0 according to Pérez Pereira's results--at the exclusion of the epenthetic /-e/ (for nouns ending in a consonant). Finally, epenthesis is correctly applied when necessary.

\section{Conclusions}

In order to understand the development of Morphology, we must first examine the development of Prosody, especially syllable structure, and Prosodic Word structure. In the present case, the acquisition of nominal plurality in Spanish, both prosodic aspects must be considered: Only children producing a high percentage of target final codas in their early productions are able to produce the final /-s/ of plural from the beginning of their plural utterances. Children with a low command of final codas, are not able to produce the /-s/ plural markings. This does not mean that they do not produce or understand plurality, but their Plural production is restricted to the allomorph /-e(s)/. Moreover, they may express Agreement, but in a restricted way, too, by means of forms that are recognizable as plurals, but lack final /-s/. Even children with rich coda production and correct Plural formation in isolation may fail to express Agreement between the noun and a determiner if this constitutes an unfooted syllable belonging to the PW (not the PPh), as the PW can only bear one plural marking. In conclusion, the results of our study clearly show that Morphology should not be studied on its own, independently of phonology and prosody, because the latter offer a basis on which Morphology can be formally expressed.

\section{References}

Abney, Steven P. (1987). The English Noun Phrase in its Sentential Aspect. MIT, doctoral dissertation.

Berko, Jean (1958). «The child's learning of English morphology». Word 14: 150-177. Bloom, Paul; Wynn, Karen (1997). «Linguistic cues in the acquisition of number words». Journal of Child Language 24: 511-533. 
Bernhardt, Barbara H.; Stemberger, Joe P. (1997). Handbook of Phonological Development: from the Perspective of Constraint-based Nonlinear Phonology. San Diego, CA: Academic Press.

Ewers, Heide (1999). «Schemata im mentalen Lexikon: Empirische Untersuchungen zum Erwerb der deutschen Pluralbildung». In: Meibauer, Jörg; Rothweiler, Monika (eds.). Das Lexikon im Spracherwerb. Tübingen/Basel: A. Francke, pp. 106-127.

Foley, James (1967). «Spanish plural formation». Language 43: 486-493.

Freitas, João; Miguel, Matilde; Hub Faria, Isabel (2000). «Interaction between prosody and morphosyntax: Plurals within codas in the acquisition of European Portuguese». In: Weissenborn, Jürgen; Höhle, Barbara (eds.). Approaches to Bootstrapping: Phonological, Syntactic and Neurophysiological Aspects of Early Language Acquisition. Amsterdam/ Philadelphia: Benjamins, pp. 45-58.

Harris, James W. (1980). «Nonconcatenative morphology and Spanish plurals». Journal of Linguistic Research 1: 15-31.

- (1986). «Epenthesis processes in Spanish». In: Neidle, Carol; Nuñez-Cedeño, Rafael A. (eds.). Studies in Romance Languages. Dordrecht: Foris, pp. 107-122.

- (1991). «The exponence of gender in Spanish». Linguistic Inquiry 22: 27-62.

Jakobson, Roman (1941). Kindersprache, Aphasie und allgemeine Lautgesetze. Uppsala: Alqmvist \& Wiksell.

Köpcke, Klaus-Michael (1988). «Schemas in German plural formation». Lingua 74: 303335.

- (1998). «The acquisition of plural marking in English and German revisited. Schemata vs. rules». Journal of Child Language 25: 293-319.

Lleó, Conxita (2002). «The Role of Markedness in the Acquisition of Complex Prosodic Structures in German-Spanish Bilinguals». The International Journal of Bilingualism 6: 291-314.

- (2003a). «Child prosody and filler syllables: Looking into Spanish through the optimal wwindow of acquisition». In: Montrul, Silvina; Ordóñez, Francisco (eds.). Linguistic Theory and Language Development in Hispanic Languages. Papers from the 5th Hispanic Linguistics Symposium and the 4th Conference on the Acquisition of Spanish and Portuguese. Somerville, Ma: Cascadilla Press, pp. 229-253.

- (2003b). «Prosodic licensing of coda in the acquisition of Spanish». Probus 15: 257-281.

Lleó, Conxita; Kuchenbrandt, Imme; Kehoe, Margaret; Trujillo, Cristina (2003). «Syllable final consonants in Spanish and German monolingual and bilingual acquisition». In: Müller, Natascha (ed.). (In)vulnerable Domains in Multilingualism. Amsterdam, Philadelphia: John Benjamins, pp. 191-220.

Marrero, Victoria; Aguirre, Carmen (2003). «Plural acquisition and development in Spanish». In: Montrul, Silvina; Ordóñez, Francisco (eds.). Linguistic Theory and Language Development in Hispanic Languages. Papers from the 5th Linguistics Symposium and the 4th Conference on the Acquisition of Spanish and Portuguese. Somerville: Cascadilla Press, pp. 275-296.

Mueller Gathercole, Virginia C.; Sebastián, Eugenia; Soto, Pilar (1999). «The early acquisition of Spanish verbal morphology: Across-the-board or piece-meal knowledge?» International Journal of Bilingualism 3: 133-182. 
Niedeggen-Bartke, Susanne (1999). «Flexion und Wortbildung im Spracherwerb». In: Meibauer, J.: Rothweiler, Monika (eds.). Das Lexikon im Spracherwerb. Tübingen/Basel: A. Francke, pp. 208-228.

Oellingrath, Julia (2003). Der Erstspracherwerb des Plurals bei nominalen kategorien durch spanische Kinder. Universität Hamburg Master thesis.

Ota, Mitsuhiko (2003). The Development of Prosodic Structure in Early Words. Amsterdam: John Benjamins.

Paradis, Johanne; Genesee, Fred (1997). «On continuity and the emergence of functional categories in bilingual first-language acquisition». Language Acquisition 6: 91-124.

Park, T.-Z. (1978). «Plurals in child speech». Journal of Child Language 5: 237-250. Pérez-Pereira, Miguel (1989). «The acquisition of morphemes: Some evidence from Spanish». Journal of Psycholinguistic Research 18: 289-312.

Rakow, Martin; Lleó, Conxita (2003). «On the (un)markedness of spirantization: Evidence from first language acquisition». In: Solé, Maria Josep; Recasens, Daniel; Romero, Joaquim (eds.). Proceedings of the 15th International Congress of Phonetic Sciences. Barcelona: Universitat Autònoma, pp. 1025-1028.

Real Academia Española (1931). Gramática de la lengua española. Madrid: EspasaCalpe.

Roca, Iggy (1996). «Phonology-morphology interface in Spanish plural formation: An optimality analysis». In: Kleinhenz, Ursula (ed.). Interfaces in Phonology. Berlin: Akademie Verlag, pp. 210-230.

Saltarelli, Mario (1970). «Spanish plural formation: apocope or epenthesis?» Language 46: 89-96.

Schaner-Wolles, Chris (1988). «Plural vs. Komparativerwerb im Deutschen. Von der Diskrepanz zwischen konzeptueller und morphologischer Entwicklung». In: Günther, H. (ed.). Experimentelle Studien zur Flexionsmorphologie. Hamburg: Beiträge zur Sprachwissenschft 2, pp. 155-186.

Saporta, Sol (1965). «Ordered rules, dialect differences, and historical processes». Language 41: 218-224.

Sebastián, Eugenia; Soto, Pilar; Mueller Gathercole, Virginia C. (2001). «Early verb constructs in Spanish». In: Almgren, Margareta; Barreña, Andoni; Ezeizabarrena, María-José; Idiazabal, Itzair; MacWhinney, Brian (eds.). Proceedings from the 8th International Congress of the International Association for the Study of Child Language. Somerville: Cascadilla Press, pp. 1245-1259.

Smith, Neil V. (1973). The Acquisition of Phonology. A Case Study. Cambridge: University Press.

Velleman, Shelley L. (1988). «The role of linguistic perception in later phonological development». Applied Psycholinguistics 9: 221-236.

Vihman, Marilyn (1996). Phonological Development. The Origins of Language in the Child. Blackwell: Cambridge MA \& Oxford UK.

Wegener, Heide (1995). «The German plural and its acquisition in the light of markedness theory». In: Pishwa, Hanna; Maroldt, Karl (eds.). The Development of Morphological Systematicity. Tübingen: Gunter Narr, pp. 245-261.

Wynn, Karen (1992). «Addition and subtraction by human infants». Nature 358: 749-50. Zagona, Karen (2002). The Syntax of Spanish. Cambridge, UK: C.U.P. 